\title{
DIGITAL COMIC: AN INNOVATION OF USING TOONDOO AS MEDIA TECHNOLOGY FOR TEACHING ENGLISH SHORT STORY
}

\author{
Asri Siti Fatimah \\ English Education, Faculty of Teacher Training and Education, Siliwangi University, Indonesia \\ E-mail: asrisitifatimah@unsil.ac.id \\ Santiana \\ English Education, Faculty of Teacher Training and Education, Siliwangi University, Indonesia \\ E-mail: santiana@unsil.ac.id \\ Yuyus Saputra \\ English Education, Faculty of Teacher Training and Education, Siliwangi University, Indonesia \\ E-mail: yuyussaputra@unsil.ac.id
}

\begin{abstract}
APA Citation: Fatimah, A. S., Santiana, S., \& Saputra, Y. (2019). Digital comic: An innovation of using ToonDoo as media technology for teaching English short story. English Review: Journal of English Education, 7(2), 101-108. doi: 10.25134/erjee.v7i2.1526.
\end{abstract}

\begin{abstract}
This study investigates the use of ToonDoo as media technology for teaching English short story. ToonDoo as the newest technology for creating comic or picture story is very beneficial helping teacher to creatively provide innovative strategy providing better classroom environment for the English learners, especially for those studying English short story. As the invented prose narrative shorter than a novel dealing with a few characters, short story can give an important content raising cultural awareness, linguistic awareness, motivation, and is claimed to improve all four skills. Therefore, this study aims at knowing how the implementation of ToonDoo in teaching English short story and finding out the benefits of this tool for teaching performance. To gain the data, reflective journal created by a pre-service teacher who becomes the participant of the study and interview were used to reflect the process of creating Toondoo and the process of teaching English short story using this tool. The findings showed that this tool can be used to promote students' speaking skill. Toondoo is very helpful to facilitate students' imagination promoting their speaking ability, producing better learning experience, and creating a good classroom atmosphere.
\end{abstract}

Keywords: English short story; pre-service teacher; reflection; technology; ToonDoo.

\section{INTRODUCTION}

The use of instructional media for teaching is really important helping teachers to deliver the material and create interesting activities in the classroom. Teachers may not only use traditional media such as pictures, cards, authentic materials and boards for teaching English, but they can also use song, audio visual, and instructional technology for helping them give instruction to the students. Today, there are so many instructional media for teaching English which have been introduced by several experts. It is certainly proven that technology used for teaching English grows very fast so that teachers are really helped to provide better classroom experience for the student (Fatimah \& Santiana, 2017). Thus, they will be very easy to find the media technology provided on mobile application and web-based internet that give different environment. As a result, teachers are encouraged to creatively give the suitable instructional tools in the classroom in order to guide students to achieve the learning objectives.

ToonDoo as one of the web-based applications provided on the internet is known as easy and appealing application which can be used as instructional tool the teachers to create picture and use it for teaching. Kirchoff and Cook in Fatimah and Santiana (2017) point out that ToonDoo is a free, fully online comic creator, one that offers many options for comic strip creation through a user-friendly interface. This web-based application tool is really beneficial allowing teachers to create cartoon by only choosing comic strips components, such as setting, characters, props, clip, art, and text bubble provided on its application. Its component is categorized to help users find what they are looking for and select just the right image. Moreover, they can upload pictures taken from internet or their own if they want. This feature is useful and easy to use. 
Similar to other web-based technology, teachers need to create an account by submitting name and email address to use ToonDoo. It provides fifteen options for panel layout, from one to four panels of equal or varying sizes. It also has option to create individual comic strips or to combine panels to form books (i.e., collections) of multiple strips (Kirchoff \& Cook, 2015). Moreover, this tool also consists of sharing options allowing the users to share their comic on internet. Students can select from public (where anyone can view), private (where only they can view), and shared (where they can select who views) for their product. This can create different setting and experience for the students which can increase their motivation to study. Gonzalez (2016) has found that the elaboration of the comic in ToonDoo was something very motivating for the students.

The use of comics in EFL setting is not new since it provides chronological images that provide narrative to their audience. This media is useful to stimulate students' ideas. Comics are art form that features a series of static images in fixed sequence, usually to tell a story. Typically, comics are printed on paper and text is often incorporated into the images (Yunus, et al., 2012). However, the use of comics in education context has surprisingly long history. Since the early 1940s, many scholars in the USA have investigated that the use of comic books did not give meaningful benefits. It was also stated that comics were a harmful literacy tool. In the 1970s, however, teachers began to dare to use comics books again and it becomes influential when Art Spiegelman's comics book, Maus, won the Pulitzer Prize in 1992. It proves that it can be artistically mature and literate works (Retalis as cited in Yunus et al., 2012).

Actually, there are many strengths of using comics in teaching English. Comics consist of pictures which are usually interesting for the students. Children have a natural attention to comic because of its elements. Comics can intrisically motivate the students to learn and take advantage from the extraordinary motivating power of this media. Furthermore, comics are known as a permanent, visual component, in contrast to film and animation, where the medium dictates the pace of the viewing process. The text medium is similarly permanent, but not 'pictorial'. 'Visual permanence' is distinctive to comic, as time within a comic book progresses at the pace of a reader (Willian \& Yang, as cited in Yunus et al.,
2012). Garcia cited in Gonzalez (2016) argues that there are some advantages of using comics in the classroom, specifically in the foreign language classroom in which comics can provide different content: phonetic-phonological, language or grammatical, lexical-semantic, functional and communicative, cultural or strategic. However, although comics only provide several pictures and a few words, but teacher can use this kind of media to teach elements of language. In addition, teacher is also allowed to use comics for teaching five skills: listening, understanding reading, oral interaction, speaking, and writing. As a medium used to express idea by pictures, comics can be used for teaching both receptive and productive skills. Finally, it is also interesting for people in which its playful component favors the teachinglearning through playing. Therefore, it really motivates students to study using this media.

Therefore, the use of cartoon created by this web 2.0 technology is really appropriate to use for teaching English short story. As the invented prose narrative shorter than a novel, short story can give important content raising cultural awareness, linguistic awareness, motivation, and are claimed to improve all four skills (Parkinson \& Reid Thomas, cited in Khatib \& Nasrollahi, 2012). The use of ToonDoo for teaching English short story can allow teachers to facilitate their imagination in which they can create unfamiliar story for the students. In addition, it also makes students learn easier and provides permanence. Toondoo can reduce repetition and make remembering words easy, promote creative skills and motivate students to learn (Jylhä-Laide cited in Wilujeng \& Lan, 2015).

Previous research conducted by Gonzalez (2016) has found that comic in ToonDoo provides the opportunity for doing collaborative learning and becomes a visual literacy resource to evidence vocabulary learning with emphasis in action verbs. This study proves that ToonDoo provides the possibility of articulating technology and English contents promoting the creativity, positive perception of English classes, and interest for showing good results. Pictures produced by ToonDoo can provide visual platform engaging the students to learn and promote their interest on the material given. Especially for teaching English short story, ToonDoo is very suitable to give a chance for the teachers to creatively design pictures by themselves. Teaching English short story by using ToonDoo will also be more interesting 
because the students will not be familiar with the story given. In addition, students also have the opportunity to create cartoon books in a group and publish it in any social media. As a result, their imagination and ability to create English short story will be enhanced. Considering the previous background, therefore this study aims to answer the following questions:

1. How is the use of ToonDoo for teaching English short story?

2. What are the benefits of using ToonDoo for teaching English short story?

\section{METHOD}

This study applied reflective practice to investigate the use of ToonDoo in teaching English short story. Boud in Lewis (2013) argues that reflective practice is a generic term for those intellectual and affective activities in which individuals engage to explore their experiences in order to lead to a new understanding and appreciation. Forty-two students coming from the fourth semester in one of Universities in Indonesia are the participants of the study. They have guided to teach short story by using ToonDoo in EFL Classroom. However, one of the students was chosen as the sources of the data. He was asked to reflect his teaching performance when using ToonDoo in teaching English Short Story.

To collect the data, reflective journal and interview were used. He was asked to write his reflective journal three times; after the lecturer introduces ToonDoo; after he creates ToonDoo; and after he teaches using it for teaching English short story. To help him do reflection, reflection template proposed by Smith adapted by Widodo and Ferdiansyah (2018) is used. The template is shown in Table 1.

Table 1. Reflection template

$\begin{array}{ll}\text { a. Describing } & \begin{array}{l}\text { Write what you felt when you } \\ \text { began your teaching or what } \\ \text { you taught from the previous } \\ \text { lesson } \\ \text { b. Informing }\end{array} \\ \text { c. Confronting } & \begin{array}{l}\text { you were teaching, in what } \\ \text { ways you taught it } \\ \text { it and also how you } \\ \text { performed the task. }\end{array} \\ \text { d. Reconstructing } & \begin{array}{l}\text { Highlight the idea as a result } \\ \text { of your self-reflection on and } \\ \text { for action that you believed } \\ \text { would be useful for your next } \\ \text { teaching }\end{array} \\ \end{array}$

The collected data were then analyzed by using thematic analysis proposed by Braun, Clarke, and Rance (2014). Firstly, the data taken from reflective journal and interview were transcribed. In this phase, the data were read and re-read in order to be familiar with the depth and breadth of the content. After being familiar with the data, the data were classified into several codes. In this phase, important points related to research objectives were colored and identified whether they were relevant or not. Then, the codes were grouped which possibly have the same theme. Then, the themes were also colored differently in order to ease the process of including the codes into the appropriate theme. Furthermore, the themes were reviewed to ensure whether the themes were appropriate or not. In addition, if the themes were not appropriate, it was omitted or replaced. Finally, the themes were named as the representation of its following sub-themes. Those became the findings of this study. At the end, the data were reported in a way which can convince the reader of the merit and validity of the analysis.

\section{RESULTS AND DISCUSSION}

As one of the free comic-creating websites, ToonDoo allows teachers to easily make cartoon strips or comics and share them to their students. However, the use of comics for teaching English is not new and can be used for developing all language skills. Comics consists of pictures combined with text and other visual information which facilitate the students not only to receive information but also express ideas from those elements. In this study, the use ToonDoo in EFL setting is investigated in order to find out the use of it for teaching English short story. From the reflective journal and interview, it is found that in this study, comics are used for teaching English speaking skill.

\section{In process of teaching English short story, I use picture that I created using ToonDoo to stimulate the students to speak. I firstly show the pictures without inserting any words. I instruct the students to discuss what expression which is probably given by the characters on the picture}

In this study, the participant uses his imagination to create the cartoon strips without any text and bring it to the classroom. 


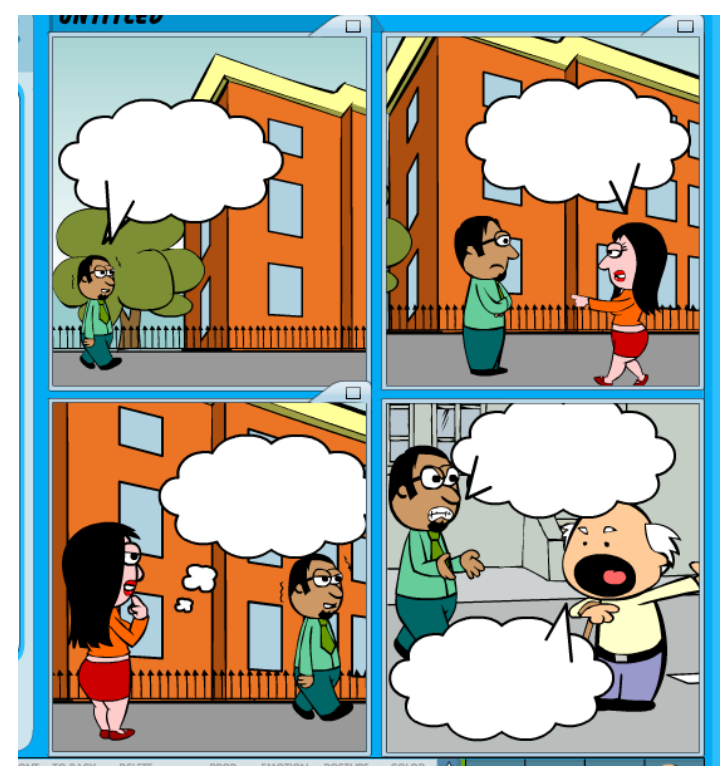

Figure 1. ToonDoo

Furthermore, the students are asked to guess the story and try to mention the expressions given by the characters. By using this activity, the students are encouraged to give their arguments about the expressions given by the characters on the comics. The findings also show that this activity engages the students to be active in the classroom. Since the goal of teaching English as a foreign language is to help students increase their communicative skills, short story provided on comics is really effective to stimulate them to speak. In the next activity, the teacher divided the students into several groups and asked them to discuss and guess the story on the comics. At the end of the activity, the students are given the opportunity to stand in front of the class to retell the story in the group. The use of ToonDoo as free online cartoon maker gets positive response from the participant as depicted in the following excerpt.

.... I am so excited to create cartoon by using Toondoo....

I really enjoy creating comic using this tool...

.... using Toondoo for creating cartoon story is really simple

Creating comics using this app is really easy. As the free cartoon maker, the participant can create free account by submitting username, password and email (Figure 2).

ToonDoo consists of hundreds characters, backgrounds and clip art which can be chosen easily by the participant (Figure 3). As stated by Tahsaldar and Seeman (2018), Toondoo Comics to Wiki Books is a great way to assess students' comprehension of story lines, and main ideas as it allows them to easily create cartoons by dragging hundreds of ready-made backgrounds, props, text boxes, and characters into the cartoon panel chosen by them.

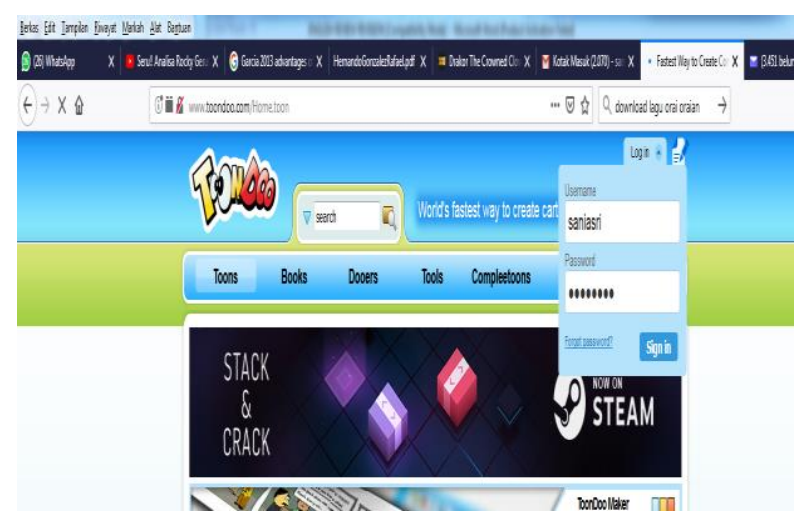

Figure 2. How to create ToonDoo

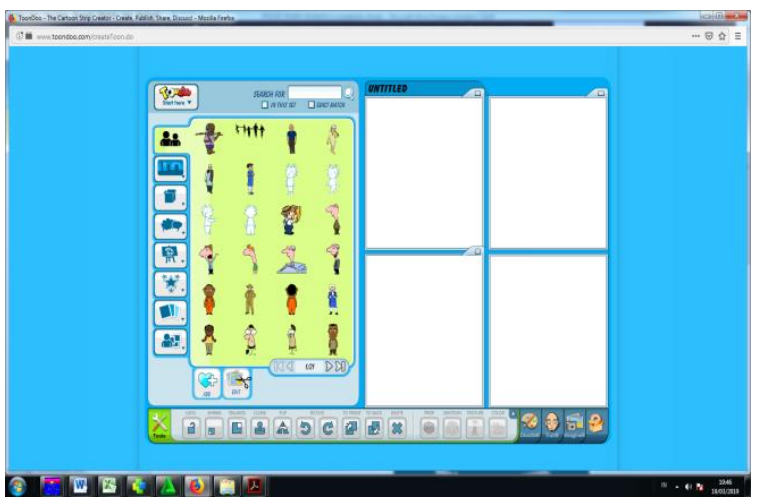

Figure 3. Characters on ToonDoo

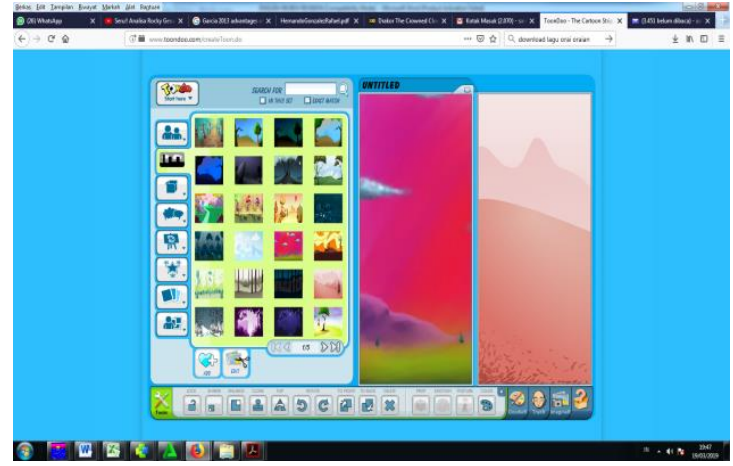

Figure 4. Background on ToonDoo

ToonDoo also provides several features which are interesting for the participant. He does not need to have a skill of drawing to create the characters. In addition, the facial expressions and body positions also can be changed easily using this tool. There are several emotions provided on the app, such as happy, angry, sad or disappointed (Figure 5). 
ENGLISH REVIEW: Journal of English Education Volume 7, Issue 2, June 2019

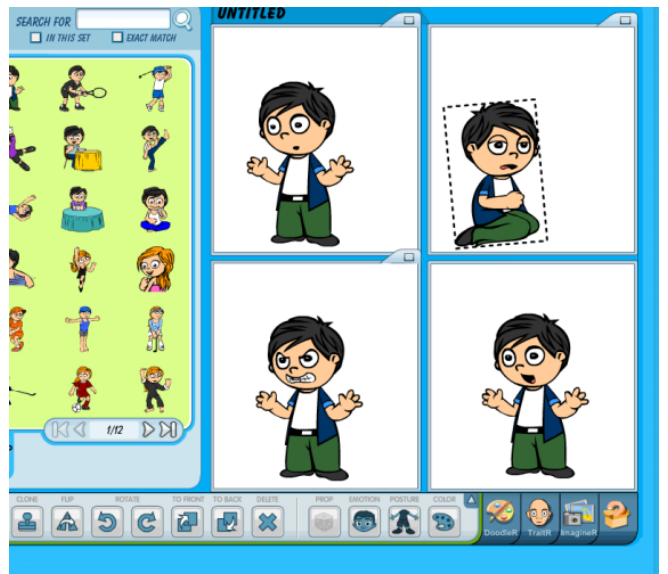

Figure 5. Facial expressions on ToonDoo

Moreover, there are also some benefits of this tool found based on themes on the data analysis. The benefits are as follows.

\section{Stimulating imagination to promote speaking skill}

The use of literature in teaching English has been previously a great debate since it provides unrealistic nature which is rarely found in daily activities. However, nowadays it has been noticed that this kind of material gives the authenticity which provides cultural augmentation and promotes linguistic awareness of the students (Parkinson \& Reid Thomas cited in Khatib \& Nasrollahi, 2012). Especially in teaching English short story, teacher can use this kind of material as the media to improve English language skill especially speaking ability.

In process of teaching English short story, I use picture that I created using ToonDoo to stimulate the students to speak. I firstly show the pictures without inserting any words. I instruct the students to discuss what expression which is probably given by the characters on the picture. The students look so enthusiastic to do these tasks. Almost all of the students give their arguments about the expressions from the characters.

The statement shows that actually teacher can use literature as media to facilitate students enhancing their language skills, especially speaking. It is supported by Khatib and Seyyed (2013) who state "short stories are claimed to improve all four skills. It can, if selected and exploited appropriately, provide quality text content which will greatly enhance ELT courses for learners at intermediate levels of proficiency."

Furthermore, the use of digital comic created by ToonDoo provides the opportunity for the students to express their ideas by guessing the
p-ISSN 2301-7554, e-ISSN 2541-3643

https://journal.uniku.ac.id/index.php/ERJEE

story on the pictures. As stated on the participant's reflection, the comic was created without any words in order to stimulate the students to guess the story and expressions which are probably given by the characters. On the other hand, it is stated by Kibedi varga cited in Conard (2016) that comics are defined as a form where images and words are received simultaneously and in series. Comics usually consists of pictures providing visual narrative and the words as the textual narrative. Comics are frequently characterized by the combination of pictures with a relatively small number of words, organized into graphically separated units in sequential order. Some researchers also agree that balloons on comic are the essential or crucial feature containing speech, text, or a caption that presents the character's voice, giving the story or 'life' to the comic. Without the text in the balloons, the reader is unable to follow the narrative of the comic. In this situation, by not providing the words on the bubbles, the students are encouraged to give their arguments to guess the expressions and also the story on the media. It is really appealing because the students can use their imagination to express their opinion about the story.

To teach English story to the students, the participant believed that using student-centered learning should be used in the classroom. This approach is known as innovative method promoting learning in communication which takes the students as active participants in their own learning.

In this meeting, I try to make the student active in the class. I do not like if they only listen to what I explain. As my lecturer says that I should use student-centered learning when teaching in the class. Therefore, this media really helps me to engage the students. After the students give their opinion about the expressions which probably occur, I ask them to guess the story of the pictures. Some of the students can guess the main idea of the story. After that, I show the expression which I previously made and tell what the story is. I also appreciate the students who can guess the story of the picture. The students look so happy and classroom situation is managed well. Finally, I ask the students to retell the story orally and write it on their handbook.

As shown on the excerpt, it is essential to use student-centered learning in the classroom. Especially when using cartoon created by ToonDoo, student-centered learning becomes 
effective since the students are encouraged to be the main characters of the classroom tasks. By providing situation in which the students express their ideas about the picture, ToonDoo helps teacher to engage the students behaviorally. As it is seen on the excerpt that almost all of the students give their argument about the story. These visual images provide textual information adding attractiveness on the atmosphere of the classroom. Wright in Lavalle and Briesmaster (2017) asserts that using pictures encourages students to use their imaginations. Thus, their ideas will be expressed easily.

\section{Exploring illustration to create better learning}

The use of ToonDoo for teaching English short story is appropriate since it facilitates teacher to easily create cartoon without having skill of drawing. ToonDoo consists of several features, such as background, characters, props and emotions which can be chosen effortlessly.

When my lecturer firstly introduces ToonDoo as one of technological tool for teaching, I am so interested. I like cartoon and in my opinion, it will be interesting for me to teach using this media. I am so excited to create cartoon by using ToonDoo. I do not need to draw pictures for creating this cartoon. I only need to choose the background and characters on this application. When my lecturer shows me the way to create cartoon by using ToonDoo, I feel happy because it is very easy and simple. I hope that I can create interesting cartoon by using this application and use it for teaching in the future.

As it is shown in the excerpt, the pre-service teacher feels excited to use this tool for teaching. This kind of application allows her to easily create the appealing instructional media for teaching. Bustamante, Hurlbut and Moeller (2012) argue, "ToonDoo proved be a valuable feature of the technology as students who are not so good at drawing their ideas with paper and pen, because they feel more comfortable creating their comic using characters from the online library located in ToonDoo". However, this tool forces her to be creative on creating the story. This application consists of several features which allow the participant to freely create her own story.

To create cartoon using ToonDoo, my obstacle is only about the story that I made. I am a perfectionist person. So that I want to create a very good story. I change the story several times because I feel not satisfied with the story. I am sometimes difficult to put my story on my cartoon because there are no character's activities that I want. Therefore, I am perforce to change the story which is suitable with the characters and its activities provided on ToonDoo.

This situation forces the participant to reflect and learn how to use this tool in order to provide a good story for the students. Ramos in Tahsaldar and Semaan (2018) highlights the importance of planning properly when using ToonDoo Comic so that students can achieve better results in learning. For more details, he added that the outline of the balloon indicates the intonation of the voice and the shape of letters indicate feelings or actions, while a larger letter indicates a screaming character and the shaky handwriting resemble a scared character and so on.

As the pre-service teacher who has less experience in teaching, the participant frequently feels anxious before coming to the class. She usually feels afraid of making mistake in teaching and cannot manage the classroom well. However, this tool helps her to be confident because it is new for the students so that it can increase their' curiosity. This web 2.0 technology allows the participant to be creative producer providing a chance to explore illustrations to create a good instructional media. By using tool, the students can also learn language well by integrating new ways of communication and expression. Ramos in Tahsaldar and Semaan (2018) explains that, if used properly and planned, the comic "can achieve concrete results in learning, such as instigating the debate and reflection on a particular theme"

\section{Creating appealing classroom atmosphere}

Creating a good classroom atmosphere becomes essential since it has a big effect on the students' behavior and motivation to learn. In this situation, teacher is encouraged to usually provide innovative strategy and tool which can make appealing classroom situation. Especially in the process of teaching short story using ToonDoo, teacher can provide unique pictures which can give different flow of the story increasing the students' curiosity and engagement in learning.

Teaching using picture especially cartoon is usually interesting. Especially when I provide story that I create by myself, the students feel 
curious. It will be different if I give the famous story, such as fable story, legend or fairy tale that are familiar for the students. They will easily know the story and will not be interested with the material that I give.

As it is shown in the previous excerpt, ToonDoo can help pre-service teacher to create new story based on her imagination. By using the media, students' emotions are easily provoked because of the flow of the story. Crumbley and Smith in Saka (2014) state that short stories connect education with entertainment in order to make learning easier and interesting. It provokes emotions, informs how people can behave and teaches something about human psychology. Furthermore, it cannot be denied that the use of pictures created by ToonDoo is really appealing. There were so many researches previously investigated the use of picture on teaching English and findings are frequently similar that it usually motivates the students and create a good classroom atmosphere (Wright in Lavalle \& Briesmaster, 2017; Mokarrama, 2017). Especially in the use of ToonDoo, sequence of pictures can add attractiveness to the classroom's atmosphere since it provides learning in a fun situation. Gonzalez (2016) argues that the elaboration of the comic in ToonDoo was something very motivating for the students as far as learning, not as significant to use it in their free time but indeed to recommend it to other students and professors as well as to use it for other subjects; also to use it as a technological tool and learn through a more fun way.

....this tool can help me to create a good classroom atmosphere...

Additionally, it has been found from the reflective journal that the classroom atmosphere is appealing since the students are engaged and active in the class. The use of ToonDoo which is new and innovative influences the students' curiosity and it develops interaction and communication in the classroom. Ramos in Tahsaldar and Semaan (2018) also added that ToonDoo Comic can be used for several education purposes, such as producing knowledge, enhancing creative writing skills, developing foreign language skills, motivating students to participate, and making classes more attractive.

\section{CONCLUSION}

ToonDoo as one of the applications to create cartoon is very beneficial helping teachers to provide different platform and appealing media in teaching English short story. As the newest technology provided on the internet, teacher can easily create cartoon using ToonDoo by only choosing background, characters and clipart provided on application. However, different with the use of picture on the book or internet, this tool encourages the teachers to be creative creating the content of the story in which the students will not be familiar with the plot of the cartoon. A student-teacher, the participant of the study, argues that this tool is really appropriate to be used for teaching English short story. To use it for teaching, bubbles on the pictures are empty in order to stimulate the students to speak by guessing the expressions which is probably given by the characters. Here, the students look so enthusiastic to give their arguments about the characters' words and also the story from the cartoon. The findings prove that literature can also be used to facilitate the students enhancing their language skill. Furthermore, the classroom situation is also interesting in which the students are engaged with the activities given by the teacher. On the other hand, teacher's professional development is also promoted in this study. It is proven form the way the teacher learns to avoid his teaching anxiety and improve creativity on creating digital comic. By using this app for teaching, she is encouraged to provide innovation in her teaching performance to create better students' language competence and ground breaking classroom situation.

\section{REFERENCES}

Braun, V., Clarke, V., \& Rance, N. (2014). How to use thematic analysis with interview data (process research). In A. Vossler \& N. Moller (Eds.), The counselling \& psychotherapy research handbook. London: Sage.

Bustamante, C. Hurlbut, S. \& Moeller, A. (2012). Web 2.0 and language learners: Moving from consumers to creators. University of NebraskaLincoln. Retrieved March 14, 2018, from http://www.csctfl.org/documents/2012Report.pd f\#page $=125$.

Conard, S. (2016). Lively letters and the graphic narrative: Revisiting comics theory on word and image through the lens of two avant-garde children's books. Image \& Narrative, 17(2).

Fatimah, A. S., \& Santiana, S. (2017). Teaching in 21st century: Students-Teachers' Perceptions of Technology Use in the Classroom. Script Journal, 2(2), 125-135. 
Gonzalez, A. M. V. (2016). Comic in ToonDoo and collaborative learning: A visual literacy resource to evidence vocabulary learning with emphasis in action verbs in an EFL group of seventh graders in a Cajicà school. Unpublished Thesis. Universidad Santo Tomás.

Khatib, M., \& Nasrollahi. (2012). Enhancing reading comprehension through short stories in Iranian EFL learners. Theory and Practice in Language Studies, 2(2), 240-246. doi:10.4304/tpls.2.2.240246.

Khatib, M., \& Seyyed, H. S. (2013). Short story based language teaching (SSBLT): A literaturebased language teaching method. International Journal of Basic Sciences \& Applied Research, 2(2), 155-159

Kirchoff, \& Cook. (2015). Overviewing software applications for graphic novel creation in the post-secondary and secondary classroom. SANE journal: Sequential Art Narrative in Education, 2.

Lavalle, P. I., \& Briesmaster, M. (2017). The study of the use of picture descriptions in enhancing communication skills among the 8th-grade students-learners of English as a foreign language. Inquiry in Education, 9(1).

Lewis, A. V. (2013). Reflective practice: What is it and how do I do it? Journal of Clinical Practice in Speech-Language Pathology, 15(2), 70-74.
Saka, Ö. (2014). Short stories in English language teaching. International Online Journal of Education and Teaching (IOJET), 1(4), 278-288.

Tahsaldar, \& Semaan. (2018). The impact of Toondoo comics on undergraduate students taking creative writing and children literature courses at the Lebanese university faculty of pedagogy. International Journal of Humanities Social Sciences and Education (IJHSSE),5(8), 203-226. doi: 10.20431/2349-0381.05080019.

Widodo, H. P., \& Ferdiansyah, S. (2018). Engaging student-teachers in video-mediated selfreflection in teaching. In K. J. Kennedy \& J. C$\mathrm{K}$. Lee (Eds), The Routledge handbook of schools and schooling in Asia. London: Routledge.

Wilujeng, \& Lan. (2015). Online comic in Mandarin Chinese's vocabulary learning: A case study of Budi Utama multilingual school in Yogyakarta, Indonesia. The IAFOR Journal of Education, III(II).

Yunus, et al. (2012). Effects of using digital comics to improve ESL writing. Research Journal of Applied Sciences, Engineering and Technology 4(18), 3462-3469. 